\title{
Plasticized Chitosan / aloe biofilms for cell regeneration
}

\section{Biopelìcula Plastificadas de Quitosano/sábila para la Regeneración Celular}

\author{
CALIXTO-OLALDE, Ma. Elena†*1', GARCÍA-CONTRERAS, René2 ${ }^{2}$ ZAMORANO-HERNÁNDEZ, \\ Julio $^{1}$ and LOUVIER-HERNÁNDEZ, José Francisco ${ }^{3}$
}

${ }^{1}$ Tecnológico Nacional de México en Irapuato, Departamento de Ingeniería en Materiales, Irapuato, Guanajuato,
${ }^{2}$ Escuela Nacional de Estudios Superiores, Unidad León, UNAM. León, Guanajuato.
${ }^{3}$ Tecnológico Nacional de México en Celaya, Departamento de Ingeniería Química, Celaya, Guanajuato, C.P: 38010

ID $1^{\text {st }}$ Author: Ma. Elena, Calixto-Olalde / ORC ID: 0000-0001-8203-3014, Researcher ID Thomson: X-3882-2019, CVU CONACYT ID: 82367

ID $1^{\text {st }}$ Coauthor: René, García-Contreras / ORC ID: 0000-0003-3504-5519, CVU CONACYT ID: 328486

ID $2^{\text {nd }}$ Coauthor: Julio, Zamorano-Hernández

ID $3^{\text {rd }}$ Coautor: José Francisco, Louvier-Hernández / ORC ID: 0000-0002-1340-9863, Researcher ID Thomson: B-24752012, CVU CONACYT ID: 201134

DOI: $10.35429 /$ EJT.2019.5.3.13.20

Received March 30, 2019; Accepted June 30, 2019

\begin{abstract}
The objective of the present work was to evaluate the effect of the incorporation of plasticizing agents; Glycerin and PVA, as well as the incorporation of aloe extract on the regeneration and / or cellular recovery capacity of plasticized chitosan. The preparation of the biofilms consisted of mixing, low molecular weight chitosan $(0.5,1$ and $1.25 \%)$, polyvinyl alcohol (1 and 1.5\%) and glycerin (3.5, 5 and 7\%). Aloe extract was incorporated in $1 \%$ together with glycerin. The drying of the films was carried out in an incubator at $28^{\circ} \mathrm{C}$ for 24 hours, using the method of slow evaporation or casting. Stress tests to determine their mechanical properties, DSC compatibility, water vapor permeability tests and through a cytotoxic activity test of biofilms using human gingival fibroblasts (HGF), the viability of the use of these biofilms in regeneration was determined mobile. A combination of chitosan / PVA / glycerin was found that exhibits good elastic properties. The DSC showed that there is a good incorporation of the components. The permeability is acceptable for the application and the cell viability tests indicate an increase thereof due to the presence of the aloe extract, as well as the plasticizers with respect to the chitosan without plasticizers.
\end{abstract}

Biofilms, Chitosan, Aloe

\begin{abstract}
Resumen
El objetivo del presente trabajo fue evaluar el efecto de la incorporación de agentes plastificantes; glicerina y PVA, así como la incorporación de extracto de sábila sobre la capacidad de regeneración y/o recuperación celular del quitosano plastificado. La preparación de las biopelículas consistió en mezclar, quitosano de bajo peso molecular $(0.5$, 1 y $1.25 \%$ ), alcohol polivinìlico (1 y $1.5 \%$ ) y glicerina $(3.5,5$ y $7 \%$ ). El extracto de sábila se incorporó en $1 \%$ junto con la glicerina. El secado de las películas se realizó en una incubadora a $28^{\circ} \mathrm{C}$ durante $24 \mathrm{~h}$, utilizando el método de evaporación lenta o "casting. Pruebas de tensión para determinar sus propiedades mecánicas, compatibilidad por DSC, pruebas de permeabilidad al vapor de agua y mediante un ensayo de actividad citotóxica de biopelículas utilizando Fibroblastos gingivales humanos (HGF), se determinó la viabilidad de la utilización de estas biopelículas en la regeneración celular. Se encontró una combinación de quitosano/PVA/glicerina que presenta buenas propiedades elásticas. El DSC mostro que existe una buena incorporación de los componentes. La permeabilidad es aceptable para la aplicación y las pruebas de viabilidad celular indican un incremento de la misma por la presencia del extracto de sábila, así como de los plastificantes respecto al quitosano sin plastificantes.
\end{abstract}

Biopelìcula, Quitosano, Sábila

Citation: CALIXTO-OLALDE, Ma. Elena, GARCÍA-CONTRERAS, René, ZAMORANO-HERNÁNDEZ, Julio and LOUVIER-HERNÁNDEZ, José Francisco. Plasticized Chitosan / aloe biofilms for cell regeneration. ECORFAN JournalTaiwan. 2019, 3-5: 13-20

\footnotetext{
* Correspondence to Author (email: macalixto@itesi.edu.mx)

$\uparrow$ Researcher contributing first author.
} 


\section{Introduction}

The development of polymeric films for biomedical uses has gained great importance due to the growing interest in the study of tissue engineering due to its large field of application; Among which the use of dressings for the recovery of damaged tissues stands out. The repair of tissue lesions by means of a similar tissue, prevents the internal environment from going outside permanently, success depends on the type and nature of the scar, dressings as an occlusive cure in a humid environment, constitute the modality in which that the pharmacist is more involved, besides being the most novel, several studies have demonstrated the beneficial effect of occlusive treatment in wound healing, which has given way to the concept of occlusive cure in a moist environment. In this area, polyurethane films, semi-occlusive hydrogels and occlusive hydrocolloid dressings have been developed.

These exert absorption and retention of the exudate, controlling the amount thereof between the dressing and the lesion [1]. Quality criteria include: autolytic debridement with wound exudate absorption; humid environment for cell migration, proliferation, differentiation and neovascularization; insulation and thermal stability; protection against infection due to impermeability to microorganisms of the external environment; fiber conservation and low allergenic potential. It is designed of an outer layer (secondary dressing), which has as a function the prevention of bacterial invasion and as a control layer in the rate of water vapor permeation, the inner layer (primary dressing) maintains the interaction with the injured tissue and It allows to drain the exudates from the wound. [two]. Among the most used materials for this purpose is chitosan and polyvinyl alcohol.

Chitosan (QT) is the polysaccharide most successfully used as a dressing, as it stimulates the regeneration of the skin. The adhesive nature of this biopolymer, together with its bactericidal, anti-fungal character and oxygen permeability are very important properties associated with the treatment of burns. However, the low mechanical resistance and the variation of some characteristics, under humid conditions limit its use in tissue engineering [2].
Polyvinyl alcohol, (PVA) is a water soluble crystalline synthetic polymer. This polymer has been widely used in the preparation of mixtures and compounds with various renewable polymers, it has also been studied for its interesting physical properties, which arise from the presence of $\mathrm{OH}$ groups and their formation of hydrogen bonds. Among the physical properties considered by polyvinyl alcohol are tensile strength and easy film formation. As well as being biocompatible, nontoxic and biodegradable

As for the plasticizer, it is important to consider that a plasticizer must comply with; compatibility and permanence. The plasticizer must be miscible with the polymer, this implies a similarity of the intermolecular forces active in the two components. [4] Therefore, glycerin or glycerol $(G)$ is considered to be the most suitable plasticizer used due to its good plasticizing efficiency and its wide availability, as well as its low price. In studies, it has been considered a very good plasticizer because it reduces intermolecular forces by increasing the mobility of the biopolymer chain and by its ability to reduce surface energy in aqueous solutions, in the same way it has been found that it has regenerative properties on the tissue. [4]

Aloe Vera or Aloe Vera (S) has therapeutic properties, its applications are both internal and external, hence it is present in numerous medicinal and beauty products, It is able to regulate the $\mathrm{pH}$ of the skin due to its ability to penetrate the dermis, epidermis and hypodermis. This allows the bacteria that clog the pores to be expelled and also help with it, to eliminate dead cells. Its use is highly recommended for insect bites, superficial wounds and burns.

Various studies have been carried out on the combination of chitosan, polyvinyl alcohol, glycerin and aloe. However, it is considered that the contribution that each of these components has on their physical and cell regeneration properties is not clear. Therefore, this work aims to evaluate the effect of the composition of the biofilm on its physical properties and cell viability, relating it to its cell regeneration capacity. [26]. 


\section{Methodology to be developed}

\section{Material}

For the preparation of the bio-films, low molecular weight chitosan (Sigma Aldrich), polyvinyl alcohol with a $99 \%$ hydrolysis degree (Sigma Aldrich), 99\% concentrated acetic acid (Sigma Aldrich) and commercial grade glycerin were used. tristilled water.

\section{Preparation of biofilms}

PVA (1 and $1.5 \% \mathrm{w} / \mathrm{v}$ ) was weighed, and added to the volume of distilled water, put to bath with water and the temperature was raised to $80^{\circ} \mathrm{C}$, until the total PVA was dissolved, allowed to cool and later To this, $1 \% \mathrm{v} / \mathrm{v}$ acetic acid was added, then in fractions the low molecular weight chitosan $(0.5,1,1.25 \%)$ was added, until the dissolution was completed, which took approximately 4 hours to eliminate bubbles present during the process of solution was left 18 hours at $180 \mathrm{rpm}, 5 \% \mathrm{v} / \mathrm{v}$ glycerin was added and the extract. It was left under stirring for 10 hours in order to completely homogenize the solution and then the process of emptying into Petri dishes, $20 \mathrm{ml}$ per box, began with those of lower concentration of the extract in order to avoid contaminating the tests.

\section{Cytotoxic activity of biofilms.}

Human gingival fibroblasts (HGF) were grown in Dulbecco's modified eagle culture medium (DMEM) supplemented with 10\% heat-fetal bovine serum (FBS), $100 \mathrm{IU} / \mathrm{mL}$ of penicillin $\mathrm{G}$ and $100 \mu \mathrm{g} / \mathrm{mL}$ of streptomycin. The HGF inoculated at a density of $1 \times 10^{5}$ cells $/ \mathrm{ml}$ and incubated at $37^{\circ} \mathrm{C}, 5 \% \mathrm{CO} 2$ and $95 \%$ relative humidity for 48 hours to allow adequate adhesion and cell density. The biofilms will be inoculated in the culture dishes for 24, 48, 72 and 96 hours. Cell viability will be determined by the MTT assay. In summary, $0.2 \mathrm{mg} / \mathrm{mL}$ of the reagent will be dissolved in culture medium and the cells will be incubated for 4 hours at $37^{\circ} \mathrm{C}$, $5 \% \mathrm{CO} 2$ and $95 \%$ humidity. Formazan will be dissolved with dimethyl sulfoxide (DMSO), cell viability by metabolic activity will be determined in a microplate reader at $570 \mathrm{~nm}$ (Multiskan go, Biochromatic Labsystem, Finland).
Analysis of cytotoxicity test results. The data analysis will be based on ISO 10993-5: 1999 E: Biological evaluation of medical devices - Part 5: Tests for in vitro cytotoxicity. Three independent experiments will be carried out in triplicate for each sample and the mean, standard deviation and percentages will be determined. The data will be submitted to Shapiro-Wilks tests and ANOVA test of a Tukey post hoc route. The statistical significance will be set with a value $\mathrm{p}<0.05$ and the 95\% reliability coefficient..

Infrared Spectroscopy (FTIR). The infrared spectra were obtained with an infrared spectrometer with PerkinElmer 77016 FT-IR brand Fourier transform.

Thermo gravimetric analysis (TGA). The analysis was performed on a TA Instruments Model 20 device in a range of 25 $600^{\circ} \mathrm{C}$, at $10^{\circ} \mathrm{C} / \mathrm{min}$ and with a flow of $\mathrm{N} 2$ $\mathrm{mL} / \mathrm{min}$.

Mechanical properties. Mechanical tests were carried out on a universal Shimadzu AGS$X$ mechanical testing machine according to ISO 527-3: 1995

\section{Water vapor permeability or WVTR}

In a Petri dish of poly styrene, $10 \mathrm{~g}$ of dry silica $(10 \mathrm{~g})$ are deposited, and the part of the lid is exposed to a surface and the box is sealed with it is put into the system at $32{ }^{\circ} \mathrm{C}$ and kept exposed to a relative humidity $50 \%$ and the evolution or change of weight is seen as time passes, following the following formula.

Permeability $=\frac{\Delta w}{t \cdot A \cdot \Delta P}=\frac{\Delta w}{t \cdot A \cdot S \cdot\left(R_{1}-R_{2}\right)}$

Where $\Delta \mathrm{w}$, is the change in weight in grams that occurs at time $t$ in hours, $A$ is the area exposed in square meters, $\mathrm{S}$ is the saturation vapor pressure in $\mathrm{mm}$ of $\mathrm{Hg}\left(1.333 \times 10^{\wedge} 2 \mathrm{~Pa}\right)$, $\mathrm{R} 1$ it is the relative humidity of the system and $\mathrm{R} 2$ is the humidity inside the box, for this case $50 \%$ and $0 \% \mathrm{RH}$, respectively.

The permeability obtained is multiplied by the thickness and the permeance of water vapor films is obtained. 


\section{Results}

\section{Synthesis conditions}

The suitable conditions of preparation and drying of the QT / PVA / G films were: stirring speed of 350 RPM, and resting before emptying in the Petri dishes to eliminate bubbles, a drying temperature at $28^{\circ} \mathrm{C}$, at which It reduces the drying time and prevents the segregation of glycerin.

\section{Characterization}

Glycerin is the plasticizer and this causes that as the amount of it increases in the film, the modulus of elasticity decreases and the \% deformation increases. The pure chitosan, presents greater module In Graph 1, the mechanical behavior, based on the $\%$ deformation of the biofilms, is presented at a fixed percentage of PVA at $1 \%$. Under these conditions, there is no trend with the increase in glycerin.

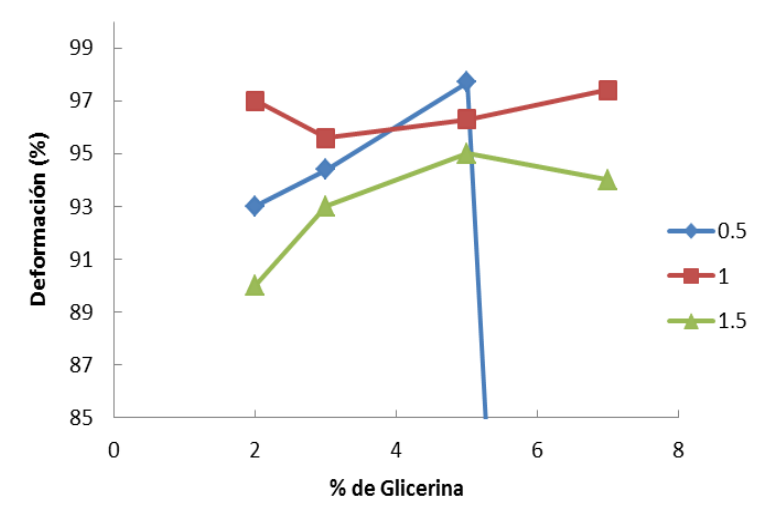

Graphic 1 Effect of the composition of the biofilm on its\% deformation at a PVA content of $1 \%$.

In the studies of glycerin addition in chitosan membranes it was found that when added, it improves the elongation properties, which gives the membranes a good manageability. The content of aloe has an insignificant effect on its mechanical properties, the variation in its modulus is minimal.

Considering the results obtained, it is determined that the composition of the base material is; QT $1 \%$, PVA 1\%, G 5\%

The infrared results indicate the presence of the components in the bioplicles, however it seems that the PVA envelops the other components, indicating a decrease in the characteristic signals of each component. The chitosan shows a characteristic signal to 1740 .

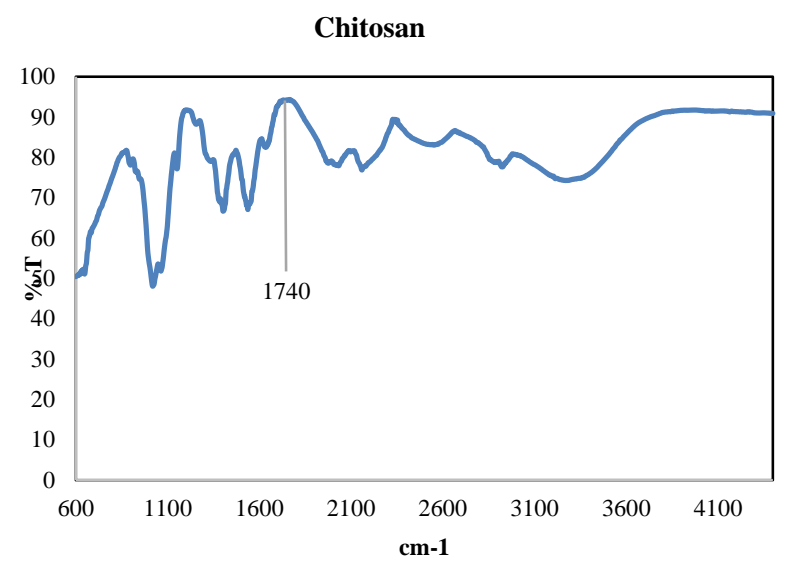

Graphic 2 ATR FTIR chitosan film

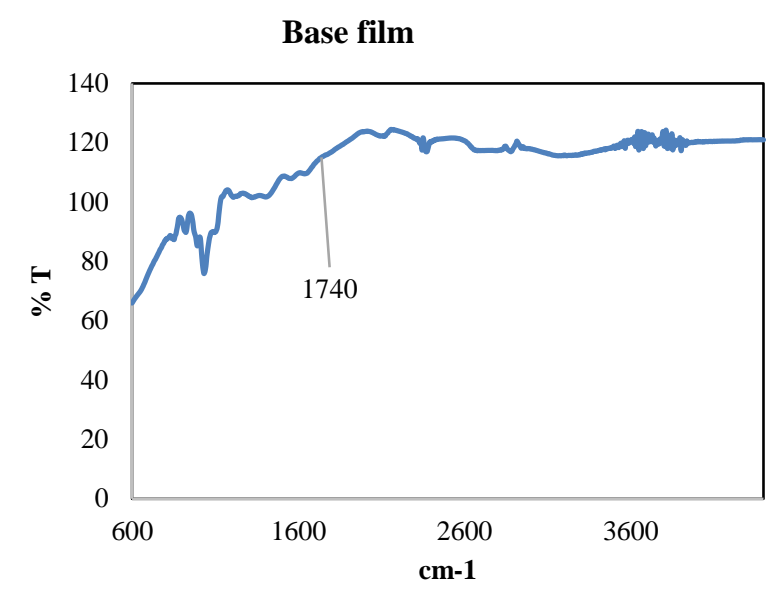

Graphic 3 ATR FTIR base film (Chitosan-Polyvinyl alcohol-Glycerin)

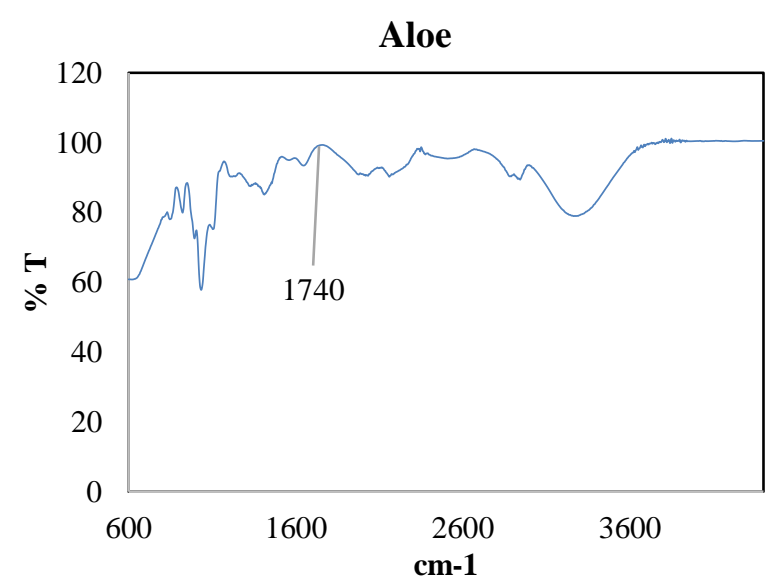

Graphic 4 ATR FTIR base film with aloe extract

The results of the thermo gravimetric analysis (TGA) indicate little effect of aloe on the thermal stability of the biofilm, which can be considered positive. The percentage of humidity stored in the samples is approximately $20 \%$ and its maximum decomposition rate is approximately $225^{\circ} \mathrm{C}$. 


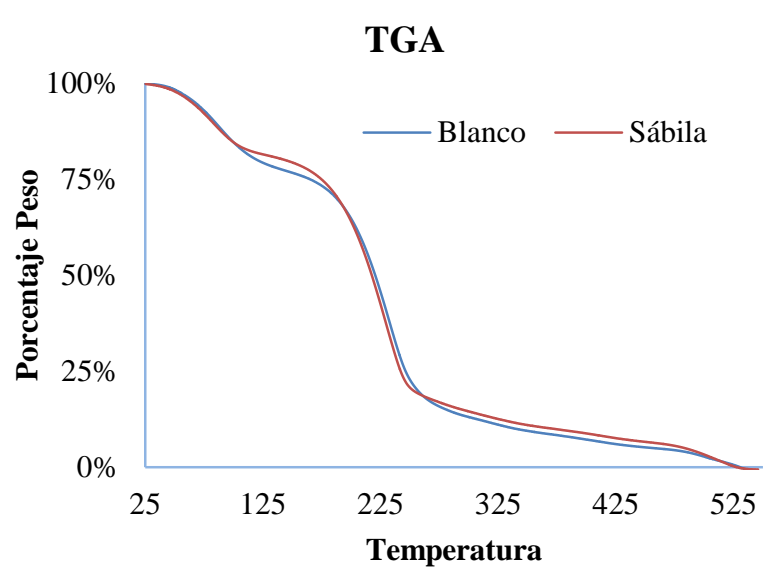

Graphic 1 TGA films of Chitosan-Poly vinyl alcoholGlycerin and QT-PVA-G-Aloe

The analysis by DSC, shows in both cases, white (base material) the characteristic peak of the Fusion PVA at $225^{\circ} \mathrm{C}$, the aloe vera makes it slightly wider which can be established as a homogeneous integration of the aloe into the base film.

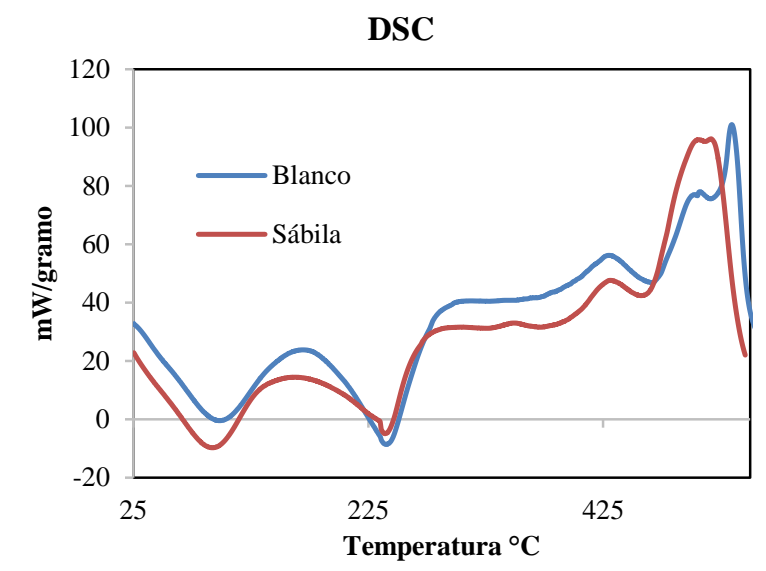

Graphic 2 DSC films white and with aloe extract

\section{Permeability}

For the chitosan / polyvinyl alcohol / glycerin membranes with aloe extract the vapor transfer rates obtained were $41 \backslash \mathrm{g} / \mathrm{m}^{\wedge} 2 \backslash \mathrm{h}$ for a $60 \mathrm{~mm}$ diameter case in an atmosphere of $50 \% \mathrm{RH}$ at 32 - C. The permeability is a function of the presence of glycerin. Therefore, it is considered that permeability can be modulated depending on the glycerin content. The values obtained allow considering it as a proposal for its application as a dressing.

\section{Cell Viability}

The cell viability results indicate that PVA in percentages greater than $1 \%$, can affect viability up to $30 \%$, however, the presence of glycerin by $5 \%$, decreases the negative effect, graphs not shown, this supports the Selection of the base composition. In general, the results obtained indicated that cytotoxicity of the films ranges from mild to moderate. Considering this base composition, the effect of the incorporation of aloe on cell viability was evaluated. Graphic 6, it is corroborated that glycerin favors cell viability and that aloe vera increases cell viability for $1 \%$ slightly above

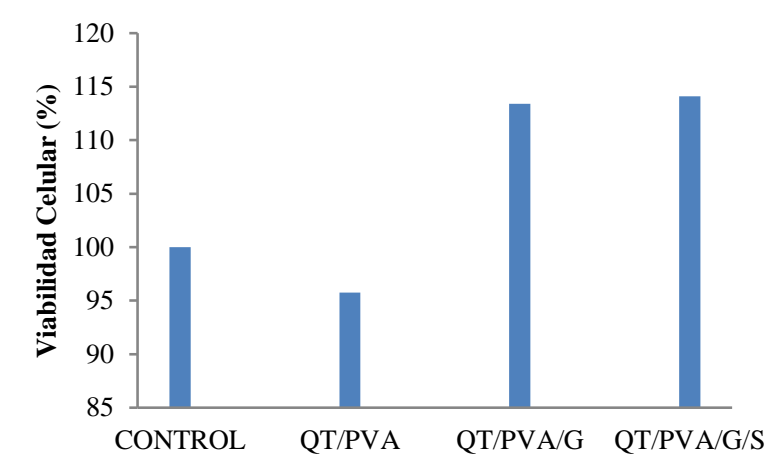

Graphic 6 Efecto de la composición sobre la viabilidad celular

\section{Agradecimiento}

I thank the Superior Technological Institute of Irapuato for the support provided for the realization of this project.

\section{Conclusions}

The biofilm synthesis conditions were established and it could be established that the $5 \%$ glycerin concentration gives the film greater elasticity, favors permeability and decreases the cytotoxicity of PVA, and in turn the PVA favors the incorporation of glycerin, avoiding segregation of it. Therefore, the composition is set at QT $1 \%$, PVA $1 \%$, and G 5\%. Aloe vera slightly increases cell viability, does not affect the mechanical properties of the base composition and stabilizes with acetic acid. 


\section{References}

[1]Valencia-Gómez, L.E., Martel-Estrada, S.A., Vargas-Requena, C.L., Rodríguez-González, C.A., \& Olivas-Armendáriz, I... (2016). Apósitos de polímeros naturales para regeneración de piel. Revista mexicana de ingeniería biomédica, 37(3), 235-249. doi:10.17488/rmib.37.3.4

[2]Martin-Aragon, S. \& Marcos, E. (2008). Tratamiento de las cicatrices. Revisión. Farmacia Profesional, 22(6), 39-43. Recuperado de: elsevier.es

[3]Trejo, Verónica, Aragón, Nidia, \& Miranda, Patricia. (2001). Estimación de la permeabilidad al vapor de agua en películas a base de quitosán. Revista de la Sociedad Química de México, 45(1), 01-05. Recuperado en 11 de septiembre de 2019, de http://www.scielo.org.mx/.

[4]Sasikala, L., Rathinamoorthy, R., \& Dhurai, B. (2018). Optimization of process conditions for chitosan-manuka honey film as wound contact layer for wound dressings. Wound Medicine, 23, 11-21. doi:10.1016/j.wndm.2018.09.007

[5]Mukherjee, D., Azamthulla, M., Santhosh, S., Dath, G., Ghosh, A., Natholia, R., Muzammil, K. M. (2018). Development and characterization of chitosan-based hydrogels as wound dressing materials. Journal of Drug Delivery Science and Technology, 46, 498-510. doi:10.1016/j.jddst.2018.06.008

[6]Liu, X., You, L., Tarafder, S., Zou, L., Fang, Z., Chen, J., Zhang, Q. (2019). Curcuminreleasing chitosan/aloe membrane for skin regeneration. Chemical Engineering Journal, 359, 1111-1119. doi:10.1016/j.cej.2018.11.073

[7]Alvarado-Morales, G., Minjares-Fuentes, R., Contreras-Esquivel, J. C., Montañez, J., MezaVelázquez, J. A., \& Femenia, A. (2019). Application of thermosonication for Aloe vera (Aloe barbadensis Miller) juice processing: Impact on the functional properties and the main bioactive polysaccharides. Ultrasonics Sonochemistry, 56, 125-133. doi:10.1016/j.ultsonch.2019.03.030
[8]Jovanović, G. D., Klaus, A. S., \& Nikšić, M. P. (2016). Antimicrobial activity of chitosan coatings and films against Listeria monocytogenes on black radish. Revista Argentina de Microbiología, 48(2), 128-136. doi: 10.1016/j.ram.2016.02.003

[9]Ouattara, B., Simard, R. E., Piette, G., Bégin, A., \& Holley, R. A. (2000). Inhibition of surface spoilage bacteria in processed meats by application of antimicrobial films prepared with chitosan. International Journal of Food Microbiology, 62(1-2), 139-148. doi: 10.1016/s0168-1605(00)00407-4

[10]Ouattara, B., Simard, R. E., Piette, G., Begin, A., \& Holley, R. A. (2000). Diffusion of Acetic and Propionic Acids from Chitosanbased Antimicrobial Packaging Films. Journal of Food Science, 65(5), 768-773. doi: 10.1111/j.1365-2621.2000.tb13584.x

[11]Ouattara, B., Simard, R. E., Holley, R. A., Piette, G. J.-P., \& Bégin, A. (1997). Inhibitory Effect of Organic Acids upon Meat Spoilage Bacteria. Journal of Food Protection, 60(3), 246-253. doi:10.4315/0362-028x-60.3.246

[12]Sánchez-González, L., Pastor, C., Vargas, M., Chiralt, A., González-Martínez, C., \& Cháfer, M. (2011). Effect of hydroxypropylmethylcellulose and chitosan coatings with and without bergamot essential oil on quality and safety of cold-stored grapes. Postharvest Biology and Technology, 60(1), 5763. doi:10.1016/j.postharvbio.2010.11.004

[13]Li, Q., Dunn, E. T., Grandmaison, E. W., \& Goosen, M. F. A. (1992). Applications and Properties of Chitosan. Journal of Bioactive and Compatible Polymers, 7(4), 370-397. doi:10.1177/088391159200700406

[14]Rabea, E. I., Badawy, M. E.-T., Stevens, C. V., Smagghe, G., \& Steurbaut, W. (2003). Chitosan as Antimicrobial Agent: Applications and Mode of Action. Biomacromolecules, 4(6), 1457-1465. doi:10.1021/bm034130m

[15]Wang, S., \& Jing, Y. (2017). Study on the barrier properties of glycerol to chitosan coating layer. Materials Letters, 209, 345-348. doi: 10.1016/j.matlet.2017.08.040 
[16]Escárcega-Galaz, A. A., Sánchez-Machado, D. I., López-Cervantes, J., Sanches-Silva, A., Madera-Santana, T. J., \& Paseiro-Losada, P. (2018). Mechanical, structural and physical aspects of chitosan-based films as antimicrobial dressings. International Journal of Biological Macromolecules, $\quad 116, \quad 472-481$. doi:10.1016/j.ijbiomac.2018.04.149

[17]Aoyagi, S., Onishi, H., \& Machida, Y. (2007). Novel chitosan wound dressing loaded with minocycline for the treatment of severe burn wounds. International Journal of Pharmaceutics, 330(1-2), 138-145. doi:10.1016/j.ijpharm.2006.09.016

[18]Ganesan, P. (2017). Natural and bio polymer curative films for wound dressing medical applications. Wound Medicine, 18, 33-40. doi:10.1016/j.wndm.2017.07.002

[19]Vargas, M., Albors, A., Chiralt, A., \& González-Martínez, C. (2011). Water interactions and microstructure of chitosanmethylcellulose composite films as affected by ionic concentration. LWT - Food Science and Technology, 44(10), 2290-2295. doi:10.1016/j.lwt.2011.02.018

[20]Halim, A. S., Nor, F. M., Mat Saad, A. Z., Mohd Nasir, N. A., Norsa'adah, B., \& Ujang, Z. (2018). Efficacy of chitosan derivative films versus hydrocolloid dressing on superficial wounds. Journal of Taibah University Medical Sciences, 13(6), 512-520. doi:10.1016/j.jtumed.2018.10.004

[21]Das, A., Uppaluri, R., \& Das, C. (2019). Feasibility of poly-vinyl alcohol/starch/glycerol/citric acid composite films for wound dressing applications. International Journal of Biological Macromolecules, $\quad 131, \quad 998-1007$. doi:10.1016/j.ijbiomac.2019.03.160

[22]Burt, S. (2004). Essential oils: their antibacterial properties and potential applications in foods - a review. International Journal of Food Microbiology, 94(3), 223-253. doi:10.1016/j.ijfoodmicro.2004.03.022

[23]Bano, I., Arshad, M., Yasin, T., \& Ghauri, M. A. (2019). Preparation, characterization and evaluation of glycerol plasticized chitosan/PVA blends for burn wounds. International Journal of Biological Macromolecules, 124, 155-162. doi:10.1016/j.ijbiomac.2018.11.073
[24]Bonilla Bonilla, María José, \& Jiménez Herrera, Luis Guillermo. (2016). Potencial industrial del Aloe vera. Revista Cubana de Farmacia, 50(1), 139-150. Recuperado de: http://scielo.sld.cu/.

[25]R., N., M., K., J., P., K.S., V., Arpana, C., Balashanmugam, P., \& Venkatasubbu, G. D. (2019). Enhanced wound healing by PVA/Chitosan/Curcumin patches: In vitro and in vivo study. Colloids and Surfaces B: Biointerfaces, $\quad 182, \quad 110339$. doi:10.1016/j.colsurfb.2019.06.068

[26]Maan, A. A., Nazir, A., Khan, M. K. I., Ahmad, T., Zia, R., Murid, M., \& Abrar, M. (2018). The therapeutic properties and applications of Aloe vera: A review. Journal of Herbal Medicine, 12, 1-10. doi:10.1016/j.hermed.2018.01.002

Aureli, P., Costantini, A., \& Zolea, S. (1992). Antimicrobial Activity of Some Plant Essential Oils Against Listeria monocytogenes. Journal of Food Protection, 55(5), 344-348. doi:10.4315/0362-028x-55.5.344

Dade, M., Galeano, P., Ríos, J. L., Rojano, B., \& Schinella, G. (2016). Apoptotic activity of isoespintanol derivatives in human polymorphonuclear cells. Revista Vitae, 23(1), 11-17. doi:10.17533/udea.vitae.v23n1a02

Hajji, S., Salem, R. B. S.-B., Hamdi, M., Jellouli, K., Ayadi, W., Nasri, M., \& Boufi, S. (2017). Nanocomposite films based on chitosanpoly(vinyl alcohol) and silver nanoparticles with high antibacterial and antioxidant activities. Process Safety and Environmental Protection, 111, 112-121. doi:10.1016/j.psep.2017.06.018

Hosseini, M. H., Razavi, S. H., \& Mousavi, M. A. (2009). Antimicrobial, physical and mechanical properties of chitosan-based films incorporated with thyme, clove and cinnamon essential oils. Journal of Food Processing and Preservation, 33(6), 727-743. doi:10.1111/j.1745-4549.2008.00307.x

Sabbah, M., Di Pierro, P., Cammarota, M., Dell'Olmo, E., Arciello, A., \& Porta, R. (2019). Development and properties of new chitosanbased films plasticized with spermidine and/or glycerol. Food Hydrocolloids, 87, 245-252. doi:10.1016/j.foodhyd.2018.08.008

CALIXTO-OLALDE, Ma. Elena, GARCÍA-CONTRERAS, René, ZAMORANO-HERNÁNDEZ, Julio and LOUVIER-HERNÁNDEZ, José Francisco. Plasticized Chitosan / aloe biofilms for cell regeneration. ECORFAN Journal-Taiwan. 2019 
Sánchez-González, L., Cháfer, M., Chiralt, A., \& González-Martínez, C. (2010). Physical properties of edible chitosan films containing bergamot essential oil and their inhibitory action on Penicillium italicum. Carbohydrate Polymers, $\quad 82(2), \quad$ 277-283. doi:10.1016/j.carbpol.2010.04.047

Sánchez-González, L., Pastor, C., Vargas, M., Chiralt, A., González-Martínez, C., \& Cháfer, M. (2011). Effect of hydroxypropylmethylcellulose and chitosan coatings with and without bergamot essential oil on quality and safety of cold-stored grapes. Postharvest Biology and Technology, 60(1), 5763. doi:10.1016/j.postharvbio.2010.11.004

Shariatinia, Z. (2019). Pharmaceutical applications of chitosan. Advances in Colloid and Interface Science, 263, 131-194. doi:10.1016/j.cis.2018.11.008

Zhang, Z.-J., Li, N., Li, H.-Z., Li, X.-J., Cao, J.M., Zhang, G.-P., \& He, D.-L. (2018). Preparation and characterization of biocomposite chitosan film containing Perilla frutescens (L.) Britt. essential oil. Industrial Crops and Products, 112, 660-667. doi:10.1016/j.indcrop.2017.12.073

Zivanovic, S., Chi, S., \& Draughon, A. F. (2005). Antimicrobial Activity of Chitosan Films Enriched with Essential Oils. Journal of Food Science, 70(1), M45-M51. doi:10.1111/j.1365-2621.2005.tb09045.x 